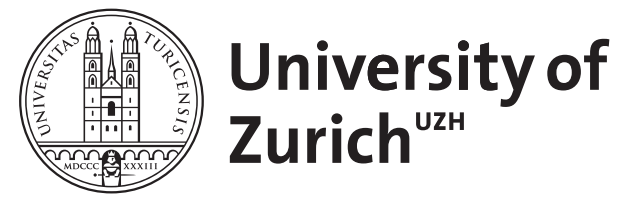
Archive

University of Zurich

University Library

Strickhofstrasse 39

CH-8057 Zurich

www.zora.uzh.ch

Year: 2006

Living-related kidney transplantation in pediatric recipients

Neuhaus, Thomas J ; Kemper, Markus J

DOI: https://doi.org/10.1007/s00467-006-0092-8

Posted at the Zurich Open Repository and Archive, University of Zurich

ZORA URL: https://doi.org/10.5167/uzh-156387

Journal Article

Published Version

Originally published at:

Neuhaus, Thomas J; Kemper, Markus J (2006). Living-related kidney transplantation in pediatric recipients. Pediatric Nephrology, 21(7):1055.

DOI: https://doi.org/10.1007/s00467-006-0092-8 


\section{Living-related kidney transplantation in pediatric recipients}

Received: 6 January 2006 / Accepted: 6 January 2006 / Published online: 25 April 2006

(C) IPNA 2006

Sirs,

We appreciate the comments of Troppmann et al. [1] concerning our previous experience [2]. Their report confirms the high degree of satisfaction of parental donors with the decision-making process and the peri- and postoperative procedures in living-related kidney transplantation (LRKT). In addition, they highlight the fact that specific circumstances in pediatric transplantation, i.e., the parent-to-child bond, is the main driving force towards LRKT, even superseding medical concerns. Although the improved operating technique, i.e., laparoscopic donor nephrectomy, did not influence the donors' perspective and decision towards LRKT, the beneficial effects of less pain and faster rehabilitation of the donors and reduced costs are welcome by all partners in the field of pediatric renal transplantation. However, the debate is still open regarding

T. J. Neuhaus $(\bowtie) \cdot$ M. J. Kemper

Department of Pediatric Nephrology,

University Children's Hospital,

Steinwiesstrasse 75 ,

8032 Zurich, Switzerland

e-mail: thomas.neuhaus@kispi.unizh.ch

Tel.: +41-44-2667111

Fax: +41-44-2667861 some concerns that laparoscopic donor nephrectomy might be a risk factor for delayed graft function and acute rejection in young recipients [3], although long-term graft function was not impaired $[4,5]$.

\section{References}

1. Troppmann C, Johnston WK III, Pierce JL, McVicar JP, Perez RV (2006) Impact of laparoscopic nephrectomy on donor preoperative decision-making and postoperative quality of life and psychosocial outcomes. Pediatr Nephrol http://dx.doi. org/10.1007/s00467-006-0093-7

2. Neuhaus TJ, Wartmann M, Weber M, Landolt MA, Laube GF, Kemper MJ (2005) Psychosocial impact of living-related kidney transplantation on donors and partners. Pediatr Nephrol 20:205-209

3. Troppmann C, McBride MA, Baker TJ, Perez RV (2005) Laparoscopic live donor nephrectomy: a risk factor for delayed function and rejection in pediatric kidney recipients? A UNOS analysis. Am J Transplant 5:175-182

4. Troppmann C, Pierce JL, Wiesmann KM, et al (2002) Early and late recipient graft function and donor outcome after laparoscopic vs open adult live donor nephrectomy for pediatric renal transplantation. Arch Surg 137:908-915; discussion 915-916

5. Singer JS, Ettenger RB, Gore JL, et al (2005) Laparoscopic versus open renal procurement for pediatric recipients of living donor renal transplantation. Am J Transplant 5:2514-2520 